\title{
Epidemiology and outcome of patients with postoperative abdominal fistula
}

\section{Perfil epidemiológico, incidência e desfecho dos pacientes com fístula abdominal pós-operatória}

Janaina Wercka ${ }^{1}$; Patricia Paola Cagol ${ }^{2}$; André luiz Parizi Melo1; Giovani de Figueiredo locks33; Orli Franzon, TCBC-SC ${ }^{1}$; Nicolau FERNANDES KRUEL, ECBC-SC'1.

\section{A B S T R A C T}

Objective: to present the epidemiological profile, incidence and outcome of patients who developing postoperative abdominal fistula. Methods: This observational, cross-sectional, prospective study evaluated patients undergoing abdominal surgery. We studied the epidemiological profile, the incidence of postoperative fistulas and their characteristics, the outcome of this complication and the predictors of mortality. Results: The sample consisted of 1,148 patients. The incidence of fistula was $5.5 \%$. There was predominance of biliary fistula $(26 \%)$, followed by colonic fistulas (22\%) and stomach (15\%). The average time to onset of fistula was 6.3 days. For closure, the average was 25.6 days. The mortality rate of patients with fistula was $25.4 \%$. Predictors of mortality in patients who developed fistula were age over 60 years, presence of comorbidities, fistula closure time more than 19 days, no spontaneous closure of the fistula, malnutrition, sepsis and need for admission to the Intensive Care Unit . Conclusion: abdominal postoperative fistulas are still relatively frequent and associated with significant morbidity and mortality.

Keywords: Epidemiology. Incidence. Fistula. Digestive System Fistula. Postoperative Complications.

\section{INTRODUCTION}

D igestive or gastrointestinal fistula is one of the most feared postoperative complications along with dehiscence and infection ${ }^{1,2}$. The topic is of great interest to the surgeon and in spite of numerous publications about it, a number of aspects related to digestive fistulas always deserves consideration.

Gastrointestinal or digestive fistula is an aberrant communication between the gut and any hollow viscus or the abdominal cavity (internal fistula), or with the skin surface (external fistula). Fistulas can be classified according to the anatomical location (gastric, pancreatic, duodenal, jejunal, ileal or colonic), output (high output $>500 \mathrm{ml} / 24 \mathrm{~h}$, and low output $<500 \mathrm{ml} / 24 \mathrm{~h}$ ), origin (congenital or acquired) or as primary (due to intestinal disease processes), or secondary (surgery) ${ }^{2,3}$. Acquired fistulas can be inflammatory / infectious, neoplastic or traumatic ${ }^{3}$.

Fistulas usually appear in the first week after surgery, with its highest peak around the fifth to the seventh days, which requires a strict postoperative evaluation, especially in patients with increased risk of developing such complications ${ }^{4}$. The main causes of death related to fistulas are malnutrition, electrolyte imbalance and sepsis. Another important factor that is associated with poor prognosis is the fistula high initial output.

At admission, about $35 \%$ to $40 \%$ of general surgery patients have some degree of malnutrition that may interfere with surgical outcomes ${ }^{5}$, with increase in length of stay, with the need for reoperations and complications, which increase hospital costs and patients' suffering.

The mortality rate for most elective surgical procedures is less than $2 \%$. However, in patients with gastrointestinal fistula mortality ranges from $6 \%$ to $48 \%$, even after advances made in its treatment ${ }^{6,7}$.

The treatment of a gastrointestinal fistula, especially the high output one, is a complex procedure that requires multi-professional work and dynamic and individualized approaches. Clinical and

1 - Hospital Regional de São José Homero de Miranda Gomes, São Jose, SC, Brasil; 2 - Curso de Medicina da Universidade do Sul de Santa Catarina

- UNISUL, Palhoça, SC, Brasil; 3 - Departamento de Anestesiologia da Universidade Federal de Santa Catarina - UFSC, SC, Brasil; 
surgical measures do not compete, but join each other at different treatment stages in search of the fistula closure?

The topic is of great interest to the surgeon and always deserves consideration. This study aims to present the epidemiological profile, incidence, predictors of mortality and outcome of patients with abdominal postoperative fistula.

\section{METHODS}

This is an observational, cross-sectional, prospective study in a referral service in General Surgery. We evaluated patients undergoing abdominal surgery operated by the specialties of General Surgery, Coloproctology, Thoracic Surgery and Urology. We evaluated 1,615 patients in the period from April 1, 2013 to June 31, 2014. We excluded 467 patients who had surgery with access to the abdomen, resulting in a final sample of 1,148 patients.

From a form designed for this study, we collected epidemiological data of patients and operations that occurred in the period. We considered only the main procedure, since some patients underwent multiple surgeries.

We assessed the presence of preoperative risk factors and outcome among patients who developed postoperative fistula. Malignant disease, age equal to or over 60 years, hypertension, diabetes, inflammatory bowel disease and immune deficiency (defined as patients who were in chronic use of corticosteroids, prior use of chemotherapy or radiotherapy, patients with HIV, malnourished with albumin levels lower than $3 \mathrm{~g} / \mathrm{dl}$, or transferrin below $150 \mathrm{mg} / \mathrm{dl}$ ).

After surgery, we searched for the occurrence of spontaneous closure and the need for surgery, whether for the fistula or for the peritonitis resulting from it. We also evaluated the occurrence of malnutrition and the need for prolonged use (more than seven days) of total parenteral nutrition, clinical outcomes with sepsis, need for admission to the Intensive Care Unit (ICU) and the death rate of patients who had postoperative fistula.
We described data as median, standard deviation (minimum and maximum) or absolute frequency (percentage). To study the association between categorical variables and death we used the Fisher test and computed the relative risk and 95\% confidence interval. We used the median to determine the cutoffs for the number of days for the diagnosis and fistula closure.

This study was approved by the Ethics in Research Committee with Human Beings according to the opinion 645,873 .

\section{RESULTS}

The study included 1,148 patients operated within 14 months. The mean age was 44.4 years, ranging from 14 to 94 . There was a similar occurrence between genders, with predominance of emergency procedures. We recorded 63 cases of fistula, corresponding to an incidence of $5.5 \%$, the most frequent complication in elective surgery, as described in Table 1.

The most frequent surgeries were for inflammatory and obstructive abdomen, or blunt, hemorrhagic or penetrating abdominal trauma. The procedures performed are listed in Figure 1.

Among the 63 patients who developed postoperative fistula, $49 \%$ were elderly or had hypertension or diabetes, and $29 \%$ underwent surgery

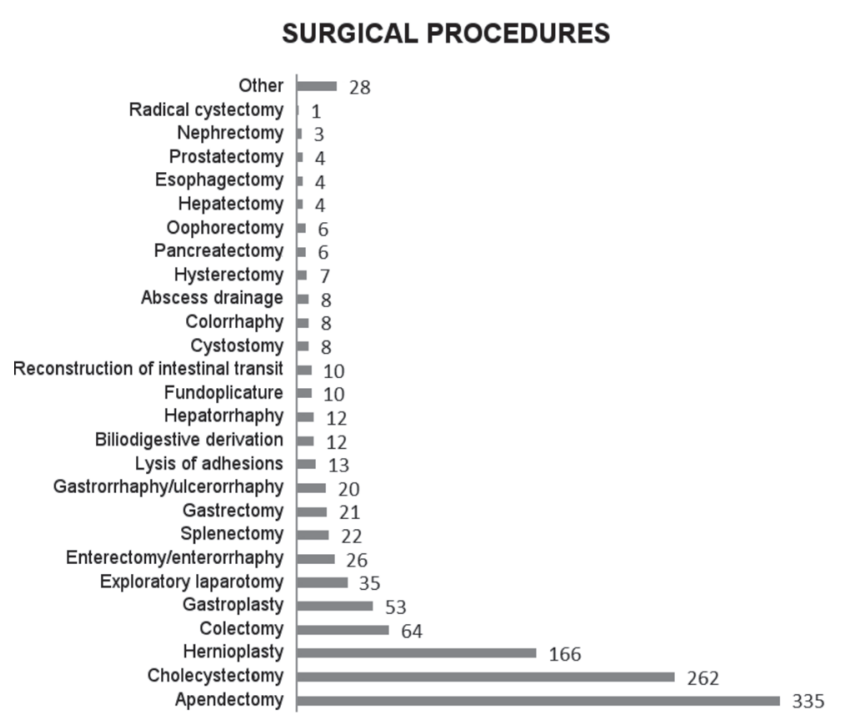

Figure 1. Main operative procedure performed in patients enrolled in the study $(n=1148)$. 
Table 1. Sample distribution according to gender, age and surgery character $(n=1148)$.

\begin{tabular}{|c|c|c|c|}
\hline & $\begin{array}{l}\text { Without fistula } \\
\qquad n=1085\end{array}$ & $\begin{array}{l}\text { With fistula } \\
n=63\end{array}$ & $P<0,005$ \\
\hline Age (years)* & $44( \pm 17,5)$ & $51,9( \pm 15)$ & $<0,01$ \\
\hline $\begin{array}{l}\text { Gender } \\
\text { Male } \\
\text { Female }\end{array}$ & $\begin{array}{l}612(56,4) \\
473(43,6)\end{array}$ & $\begin{array}{l}34(53,4) \\
29(46,6)\end{array}$ & $<0,70$ \\
\hline $\begin{array}{c}\text { Surgery chara } \\
\text { Elective } \\
\text { Urgency }\end{array}$ & $\begin{array}{l}420(38,7) \\
665(61,3)\end{array}$ & $\begin{array}{l}38(60,3) \\
25(39,7)\end{array}$ & $<0,001$ \\
\hline
\end{tabular}

* Data presented in mean \pm standard deviation.

Table 2. Presence of risk factors among patients who developed postoperative fistula.

\begin{tabular}{lc}
\hline \multicolumn{1}{c}{ Risk factors prior to surgery } & $\mathrm{n}=63(\%)$ \\
\hline Malignant disease & $20(32)$ \\
Immunosuppression & $26(41)$ \\
Hypertension/Diabetes/Advanced Age & $31(49)$ \\
Surgery in the presence of infection & $18(29)$ \\
Inflammatory bowel disease & $5(8)$ \\
\hline
\end{tabular}

Table 3. Characteristics of postoperative fistulas found in the study.

\begin{tabular}{lc}
\hline Characteristics of fistulas & $\mathrm{n}=63(\%)$ \\
\hline Location & $18(28,6)$ \\
Biliary & $14(22,2)$ \\
Colon & $10(15,9)$ \\
Stomach & $9(14,3)$ \\
Jejunoileal & $4(6,3)$ \\
Esophagus & $2(3,2)$ \\
Duodenum & $2(3,2)$ \\
Pancreas & $2(3,2)$ \\
Bladder & $2(3,2)$ \\
Rectum & \\
Fistula debit & $13(21)$ \\
High & $50(79)$ \\
Low & \\
Drainage location & $12(19)$ \\
Internal & $51(81)$ \\
External (enterocutaneous) & \\
Path & $56(89)$ \\
Long & $7(11)$ \\
Short &
\end{tabular}

in the presence of infection. These data are shown in Table 2.

The diagnosis of postoperative fistula was performed on average 6.3 days after surgery, with a standard deviation 3.5 days (range 2 to 22). Among these patients, abdominal cavity drainage was used in 50 cases. There was a predominance of biliary fistulas, with $26 \%$. Most fistulas were of low output, external type and had a long path (Table 3).

Regarding the diagnosis of postoperative digestive fistulas, we observed alterations in clinical signs, predominantly abdominal pain, abnormal abdominal examination, tachycardia, vomiting and fever. As diagnostic complement, we used abdomen $\mathrm{CT}$, oral test with methylene blue, endoscopy, colonoscopy and fistulography. As for the drainage of the fistula content, the majority of patients had exteriorization. Table 4 shows the complementary methods for the diagnosis of postoperative fistulas and their forms of.

Table 4. Diagnostic methods used in patients who developed postoperative fistula and forms of exteriorization.

\begin{tabular}{lc}
\hline \multicolumn{1}{c}{ Diagnosis } & $\mathrm{n}=63(\%)$ \\
\hline Diagnostic Tests & $5(8)$ \\
Computerized Tomography & $7(11)$ \\
Methylene blue & $4(6)$ \\
Digestive Endoscopy & $7(11)$ \\
Fistulografy & $1(2)$ \\
Colonoscopy & $51(81)$ \\
Exteriorization & $33(52)$ \\
Through drain & $7(11)$ \\
Through surgical wound & $11(17)$ \\
Through drain and surgical wound &
\end{tabular}


There was spontaneous fistula closure in 19 patients (30\%). The average time for fistula closure was $25.6 \pm 19.3$ days (range $8-89$ ). Reoperation for the treatment of fistulas was necessary in 32 patients $(47.6 \%)$ and surgery for the treatment of peritonitis was performed in 35 cases (56\%). We observed malnutrition in 32 patients $(51 \%)$, of whom $11(18 \%)$ required parenteral nutrition for more than seven days. Sepsis ensued in 46 patients (73\%). In 32 cases $(51 \%)$, their conditions required ICU admission. There were 16 deaths, with a mortality rate of $25.4 \%$.

Factors that were associated with mortality among patients who developed fistula were age over 60 years, presence of comorbidities, no spontaneous closure of the fistula or closure after 19 days, malnutrition, sepsis and need for ICU (Table 5).

\section{DISCUSSION}

Among 1,148 patients, there were 63 cases of fistulas, corresponding to $5.5 \%$. This rate is within the standard of other studies 8 . The mean age was 44.4 years, with no difference between genders. Visschers et al. ${ }^{9}$ reported an average age of 59 years, $56 \%$ being male. Bradley et al. ${ }^{8}$ found that $20 \%$ of patients were older than 55 years, with a $79 \%$ prevalence of men 8,9 .

There was a predominance of emergency surgery, but the incidence of fistula was observed with the highest proportion in elective procedures $(60.3 \%)$, corroborating the study of Torres et al. ${ }^{5}$, who found that $69.2 \%$ of fistulas took place in elective surgeries. Urgent surgery is a risk factor related to preoperative preparation, since the time for them tends to be shorter, acting as a prognostic factor ${ }^{5-9}$. There is thus an increased risk of complications, which was not observed in this study.

The most frequent fistulas were biliary and colonic, followed by gastric, this sequence being different from the one a study of 188 patients, which showed predominance of jejunoileal $(28.7 \%)$, biliopancreatic $(24,9 \%)$ and colonic (23.9\%) fistulas. The characteristics shown by most fistulas are favorable prognosis. The anatomical location is important and is assessed as a risk factor for worse prognosis ${ }^{10}$.

The average time for the fistula closure was 6.3 days (range 2-22). In an Israeli study with 389 patients, Bala et al. showed that the average time for spontaneous closure was eight days, ranging from five to $19^{10}$.

Most fistulas were of low output, which means lower loss of a complete solution that is rich in protein, electrolytes and complexes that could lead to electrolyte disturbances ${ }^{11}$.

Total parenteral nutrition (TPN) extending longer than seven days was assessed in this study and showed no statistical significance. However, some studies have shown that the prolonged use of TPN leads to worse prognosis, further reducing protein rate and increasing catabolism. Malnutrition can be both a cause and a result of this anatomical and metabolic instability ${ }^{10-12}$.

Patients without complications remain hospitalized on average 14.24 days less than patients with complications ${ }^{11}$.

The spontaneous closure of the fistula occurred in $30 \%$ of cases, on average after 25.6 days, shorter than that observed by Pepe et al. in 2014, a mean time of spontaneous closure of 36.4 days $^{4}$. As for fistula management, $47.6 \%$ required surgical reintervention in this study, also a lower rate than that observed by Pepe et al., which was $69 \%{ }^{4}$.

In our study, 16 patients died (25.4\%), a high mortality rate, but within a range of $6 \%$ to $33 \%$ observed in a meta-analysis published in $2012^{13}$.

The treatment of digestive fistulas advanced considerably in recent decades, but is still a thorny issue for the surgeon. Early diagnosis and prompt institution of treatment, infection control, fistula path orientation and electrolyte and nutritional support measures are capable of reducing complications and mortality ${ }^{13-16}$.

In conclusion, the incidence of postoperative fistula was 5.5\%, more than $50 \%$ being after elective surgeries and $26 \%$ of biliary type. Most were of low output and had a long path. Mortality was $25.4 \%$. 
Table 5. Factors associated with mortality in patients with fistula.

\begin{tabular}{|c|c|c|c|c|}
\hline Variable & Survival (\%) & Death (\%) & $p$ & RR (IC) \\
\hline \multicolumn{5}{|l|}{ Age $>60$} \\
\hline Yes & $10(15,8)$ & $9(14,2)$ & 0,008 & $1,6(1,02-2,50)$ \\
\hline No & $37(58,7)$ & $7(11,3)$ & & \\
\hline \multicolumn{5}{|l|}{ Male } \\
\hline Yes & $28(44,4)$ & $6(9,5)$ & 0,13 & $1,26(0,92-1,7)$ \\
\hline No & $19(30,1)$ & $10(15,8)$ & & \\
\hline \multicolumn{5}{|l|}{ Emergency surgery } \\
\hline Yes & $18(28,5)$ & $7(11,3)$ & 0,70 & $1,06(0,78-1,43)$ \\
\hline No & $29(46)$ & $9(14,2)$ & & \\
\hline \multicolumn{5}{|l|}{ Malignant disease } \\
\hline Yes & $13(20,6)$ & $7(11,3)$ & 0,23 & $0,82(0,57-1,17)$ \\
\hline No & $34(53,9)$ & $9(14,2)$ & & \\
\hline \multicolumn{5}{|l|}{ Immunosuppression } \\
\hline Yes & $17(26,9)$ & $9(14,2)$ & 0,16 & $1,83(0,78-4,28)$ \\
\hline No & $30(47,6)$ & $7(11,3)$ & & \\
\hline \multicolumn{5}{|l|}{ Hypertension/Diabetes } \\
\hline Yes & $18(28,5)$ & $13(20,6)$ & 0,003 & $4,47(1,41-14,1)$ \\
\hline No & $29(46)$ & $3(4,7)$ & & \\
\hline \multicolumn{5}{|l|}{ Infection in surgery } \\
\hline Yes & $11(17,4)$ & $7(11,3)$ & 0,12 & $1,94(0,85-4,42)$ \\
\hline No & $36(57,1)$ & $9(14,2)$ & & \\
\hline \multicolumn{5}{|c|}{ TPN for more than seven days } \\
\hline Yes & $8(12,6)$ & $3(4,7)$ & 0,87 & $1,09(0,37-3,19)$ \\
\hline No & $39(61,9)$ & $13(20,6)$ & & \\
\hline \multicolumn{5}{|l|}{ Surgery for fistula } \\
\hline Yes & $22(35)$ & $10(15,8)$ & 0,28 & $1,61(0,67-3,91)$ \\
\hline No & $25(39,6)$ & $6(9,5)$ & & \\
\hline \multicolumn{5}{|l|}{ Surgery for peritonitis } \\
\hline Yes & $23(36,5)$ & $12(19)$ & 0,070 & $2,4(0,87-6,63)$ \\
\hline No & $24(38,0)$ & $4(6,3)$ & & \\
\hline \multicolumn{5}{|l|}{ Sepsis } \\
\hline Yes & $30(47,6)$ & $16(25,4)$ & 0,005 & $0,65(0,52-0,85)$ \\
\hline No & $17(26,9)$ & $0(0)$ & & \\
\hline \multicolumn{5}{|l|}{ Malnutrition } \\
\hline Yes & $20(31,7)$ & $12(19)$ & 0,02 & $2,90(1,05-8,04)$ \\
\hline No & $27(42,8)$ & $4(6,3)$ & & \\
\hline \multicolumn{5}{|l|}{ Admission to ICU } \\
\hline Yes & $18(28,5)$ & $14(22,2)$ & 0,001 & $6,78(1,68-27,4)$ \\
\hline No & $29(46)$ & $2(3,17)$ & & \\
\hline \multicolumn{5}{|l|}{ Spontaneous closure } \\
\hline Not closed & $29(46)$ & $15(23,8)$ & 0,01 & $1,44(1,14-1,82)$ \\
\hline Closed & $18(28,5)$ & $1(1,5)$ & & \\
\hline \multicolumn{5}{|l|}{ High debit fistula } \\
\hline Yes & $7(11,1)$ & $4(6,3)$ & 0,36 & $1,57(0,62-3,98)$ \\
\hline No & $40(63,4)$ & $12(19)$ & & \\
\hline \multicolumn{5}{|l|}{ Days to diagnosis } \\
\hline Less than 6 days & $29(46)$ & $9(14,2)$ & 0,70 & $1,06(0,78-1,4)$ \\
\hline More than 6 days & $18(28,5)$ & $7(11,1)$ & & \\
\hline \multicolumn{5}{|l|}{ Days to closure } \\
\hline Less than 19 days & $22(35)$ & $1(1,5)$ & 0,004 & $1,53(1,19-1,97)$ \\
\hline More than 19 days & $25(39,6)$ & $15(23,8)$ & & \\
\hline
\end{tabular}

* Confidence interval 95\%. TPN: Total Parenteral Nutrition. 


\section{R E S U M O}

Objetivo: apresentar o perfil epidemiológico, incidência e desfecho em pacientes que evoluíram com fístula abdominal pós-operatória. Métodos: trata-se de um estudo prospectivo transversal observacional que avaliou pacientes submetidos à cirurgia abdominal. Foram estudados o perfil epidemiológico, a incidência das fístulas pós-operatórias e suas características, desfecho desta complicação e fatores preditivos de mortalidade. Resultados: a amostra constou de 1148 pacientes. A incidência de fístula foi 5,5\%. Houve predominância de fístulas biliares (26\%), seguidas de fístulas colônicas (22\%) e gástricas (15\%). O tempo médio para o surgimento da fístula foi 6,3 dias. Para o fechamento, a média foi 25,6 dias. A taxa de mortalidade dos pacientes com fístula foi $25,4 \%$. Os fatores preditivos de mortalidade nos casos que desenvolveram fístula foram idade maior do que 60 anos, presença de comorbidades, tempo de fechamento da fistula superior a 19 dias, não fechamento espontâneo da fístula, desnutrição, sepse e necessidade de admissão em Unidade de Terapia Intensiva. Conclusão: as fístulas pós-operatórias abdominais ainda são relativamente frequentes e associadas à morbidade e mortalidade significativas.

Descritores: Epidemiologia. Incidência. Fístula. Fístula do Sistema Digestório. Complicações Pós-Operatórias.

\section{REFERENCES}

1. feifer J, Tomasch G, Uranues S. The surgical anatomy and etiology of gastrointestinal fistulas. Eur J Trauma Emerg Surg. 2011;37(3):209-13.

2. Polk TM, Schwab CW. Metabolic and nutritional support of the enterocutaneous fistula patient: a three-phase approach. World J Surg. 2012;36(3):524-33.

3. Lundy JB, Fischer JE. Historical perspectives in the care of patients with enterocutaneous fistula. Clin Colon Rectal Surg. 2010;23(3):133-41.

4. Pepe G, Magalini S, Callari C, Persiani R, Lodoli C, Gui $D$. Vacuum assisted closure (VAC) therapyTM as a swiss knife multi-tool for enteric fistula closure: tips and tricks: a pilot study. Eur Rev Med Pharmacol Sci. 2014;18(17):2527-32.

5. Torres OJM, Salazar RS, Costa JVG, Correa FCF, Malafaia O. Fístulas enterocutâneas pós-operatórias: análise de 39 pacientes. Rev Col Bras Cir. 2002;29(6):359-63.

6. Campos AC, Meguid MM, Coelho JC. Factors influencing outcome in patients with gastrointestinal fistula. Surg Clin North Am. 1990;76(5):1191-8.

7. Souza HP, Gabiatti G, Dotta F. Fistulas digestivas no trauma. Rev Col Bras Cir. 2001;28(2):13845.

8. Bradley MJ, Dubose JJ, Scalea TM, Holcomb JB, Shrestha B, Okoye O, et al. Independent predictors of enteric fistula and abdominal sepsis after damage control laparotomy: results from the prospective AAST Open Abdomen registry. JAMA Surg.
2013;148(10):947-54.

9. Visschers RG, Olde Damink SW, Winkens B, Soeters PB, van Gemert WG. Treatment strategies in 135 consecutive patients with enterocutaneous fistulas. World J Surg. 2008;32(3):445-53.

10. Bala M, Gazalla SA, Faroja M, Bloom Al, Zamir G, Rivkind $\mathrm{Al}$, et al. Complications of high grade liver injuries: management and outcome with focus on bile leaks. Scand J Trauma Resusc Emerg Med. 2012;20:20.

11. Thieme RD, Cutchma G, Chieferdecker MEM, Campos ACL. Nutricional risk index is predictor of postoperative complication in operations of digestive system or abdominal wall? ABCD, arq bras cir dig. 2013;26(4):286-92.

12. Marinis A, Gkiokas G, Argyra E, Fragulidis G, Polymeneas G, Voros D. "Enteroatmospheric fistulae"--gastrointestinal openings in the open abdomen: a review and recent proposal of a surgical technique. Scand J Surg; 2013;102(2):61-8.

13. Rahbour G, Siddiqui MR, Ullah MR, Gabe SM, Warusavitarne J, Vaizey CJ. A meta-analysis of outcomes following use of somatostatin and its analogues for the management of enterocutaneous fistulas. Ann Surg. 2012;256(6):946-54.

14. Mawdsley JE, Hollington P, Bassett P, Windsor AJ, Forbes A, Gabe SM. An analysis of predictive factors for healing and mortality in patients with enterocutaneous fistulas. Aliment Pharmacol Ther. 2008;28(9):1111-21.

15. Lu CY, Wu DC, Wu IC, Chu KS, Sun LC, Shih $\mathrm{YL}$, et al. Serum albumin level in the manage- 
ment of postoperative enteric fistula for gastrointestinal cancer patients. J Investig Surg. 2008;21(1):25-32.

16. Visschers RG, van Gemert WG, Winkens B, Soeters PB, Olde Damink SW. Guided treatment improves outcome of patients with enterocutaneous fistulas. World J Surg. 2012;36(10):2341-8.
Received: 09/12/2015

Accepted for publication: 28/03/2016 Conflict of interest: none.

Source of funding: none.

Mailing address:

Janaina Wercka

E-mail: drajanainawercka@yahoo.com.br 